the CFP foreign affairs seminar for more than two decades

Norman J. Ornstein, 1969-70 Congressional Fellow and American Enterprise Institute Resident Scholar

Bill Koetzle, 1997-98 Congressional Fellow and legislative director to House Speaker Dennis Hastert

George Kundanis, 1976-77 Congressional Fellow and senior assistant to House Democratic Leader Richard Gephardt

Paul Light, 1982-83 Congressional Fellow and vice president and director of governmental studies at The Brookings Institution

Thomas Mann, 1969-70 Congressional Fellow, former CFP director, APSA executive director, 1999 Goodnow Award winner, and senior scholar at The Brookings Institution

Jim Thurber, 1973-74 Congressional Fellow and professor and director of the center for Congressional and Presidential Studies at American University.

If there were ever a question as to how dependent the APSA Congressional Fellowship Program is on its alumni, the list of these "faculty" answers the question: a very great deal.

\section{APSA Welcomes New Section on Interdisciplinary Approaches to International History and Politics}

During their meeting on September 1, members of APSA's Council approved the establishment of an Organized Section on Interdisciplinary Approaches to International History and Politics.

Section organizers have set themselves the goals of promoting the study of international history and politics, encouraging interdisciplinary conversations between political scientists and historians, advancing the development, dissemination, integration, and application of qualitative and historiographical methodologies, and distributing research results derived from the application of such methodologies. The section's first president, Alexander George, has also expressed his hope that the section will provide an institutional focus for the recent resurgence in the qualitative study of international politics and serve as a permanent point of access for dialogue between international, diplomatic, economic, and military historians and political scientists who study international relations and foreign affairs.

The section welcomes all scholars and scholarship that intersect with its purposes, regardless of their preferred methodology or epistemology. Annual dues are $\$ 5$, and can be paid as part of the APSA membership renewal. Members wishing to join the section before they are asked to renew their APSA memberships should contact APSA at 202-4832512 or membership@apsanet.org.

More information regarding the goals and purposes of the section can be found on APSA's web site (www.apsanet.org/about/sections). Specific questions should be directed to Section Vice President Andrew Bennett (202-687-5800; bennetta@gunet.georgetown.edu) or Section Secretary-Treasurer Colin Elman (617-495-1035; colin-elman@harvard.edu).

\section{Section News}

Political Psychology

- At their 1999 business meeting, section officers honored Robert Lane by naming its annual book award for him. They also honored Margaret $\mathrm{M}$. Hermann by naming the section's graduate student scholarship award for her. The scholarship makes it possible for a student to attend the OSU-ISPP Summer Institute in Political Psychology. They also discussed plans to raise funds for endowing these awards and supporting others. In other business, section officers named Diana Mutz and Robert Jervis members of the 1999 book award committee.

- Political Psychology Division Chair Stanley Feldman, SUNY-Stony Brook, organized nine section panels for the Annual Meeting Program, which were well attended. Laura Stoker, University of California, Berkeley, will serve as division chair for the 2000 meeting.

- The newsletter of the section, The Political Psychologist, is now being coedited by Stanley Feldman, Leonie Huddy, and Milton Lodge at
SUNY-Stony Brook. From 1996 to 1998 , it was produced by the Center for the Study of Political Psychology at the University of Minne sota. The spring 1999 issue focused on political and social identity and featured contributions by Katherine Cramer, Marc Howard Ross, David O. Sears, P.J. Henry, and Marilynn Brewer. The next issue will include articles on issue framing.

\section{Organized Sections Distribute Awards at Annual Meeting}

At their respective meetings during APSA's 1999 Annual Meeting in Atlanta, Organized Sections presented over 50 awards recognizing dissertations, books, papers, and careers. Many of these section prizes are annual and nominations are sought at this time for next year's awards. For further information be sure to visit APSANet (www. apsanet.org/about/sections).

\section{Federalism and Intergovernmental Relations}

The Distinguished Scholar Award, recognizing distinguished scholarly contributions to the study of federalism and intergovernmental relations, was presented to Joseph Zimmerman, a member of the department of political science at University at Albany-SUNY. The Best Paper Award was conferred upon Troy Smith of Brigham Young University for his paper, "When States Lobby: Welfare Reform, 1993-1997." The Best Book Award, given for the best book on federalism and intergovernmental relations published at least 10 years ago that has made a lasting contribution to the study of federalism and intergovernmental relations, was presented to Vincent Ostrom of Indiana University for The Political Theory of the Compound Republic (Public Choice, 1971)

\section{Law and Courts}

Members of the Law and Courts section saw the American Judicature Society Award conferred upon Melinda Gann Hall of Michigan State University for her paper, 